\title{
Direct $\mathrm{O}_{2}$ control on the partitioning between denitrification and dissimilatory nitrate reduction to ammonium in lake sediments
}

\author{
Adeline N. Y. Cojean ${ }^{1, a}$, Jakob Zopfi ${ }^{1}$, Alan Gerster ${ }^{1}$, Claudia Frey $^{1}$, Fabio Lepori ${ }^{2}$, and Moritz F. Lehmann ${ }^{1}$ \\ ${ }^{1}$ Aquatic and Stable Isotope Biogeochemistry, University of Basel, Bernoullistrasse 30, 4056 Basel, Switzerland \\ ${ }^{2}$ Institute of Earth Science, Scuola Universitaria Professionale della Svizzera Italiana (SUPSI), \\ Trevano, 6952 Canobbio, Switzerland \\ a now at: Centre for Hydrogeology and Geothermics (CHYN), University of Neuchâtel, \\ Rue Emile Argand 11, 2000 Neuchâtel, Switzerland
}

Correspondence: Adeline N. Y. Cojean (adeline.cojean@unine.ch)

Received: 25 June 2019 - Discussion started: 2 July 2019

Revised: 28 October 2019 - Accepted: 29 October 2019 - Published: 10 December 2019

\begin{abstract}
Lacustrine sediments are important sites of fixednitrogen $(\mathrm{N})$ elimination through the reduction of nitrate to $\mathrm{N}_{2}$ by denitrifying bacteria, and they are thus critical for the mitigation of anthropogenic loading of fixed $\mathrm{N}$ in lakes. In contrast, dissimilatory nitrate reduction to ammonium (DNRA) retains bioavailable $\mathrm{N}$ within the system, promoting internal eutrophication. Both processes are thought to occur under oxygen-depleted conditions, but the exact $\mathrm{O}_{2}$ concentration thresholds particularly of DNRA inhibition are uncertain. In $\mathrm{O}_{2}$ manipulation laboratory experiments with dilute sediment slurries and ${ }^{15} \mathrm{NO}_{3}^{-}$additions at lowto sub-micromolar $\mathrm{O}_{2}$ levels, we investigated how, and to what extent, oxygen controls the balance between DNRA and denitrification in lake sediments. In all $\mathrm{O}_{2}$-amended treatments, oxygen significantly inhibited both denitrification and DNRA compared to anoxic controls, but even at relatively high $\mathrm{O}_{2}$ concentrations $\left(\geq 70 \mu \mathrm{mol} \mathrm{L}{ }^{-1}\right)$, nitrate reduction by both denitrification and DNRA was observed, suggesting a relatively high $\mathrm{O}_{2}$ tolerance. Nevertheless, differential $\mathrm{O}_{2}$ control and inhibition effects were observed for denitrification versus DNRA in the sediment slurries. Below $1 \mu \mathrm{mol} \mathrm{L} \mathrm{O}_{2}^{-1}$, denitrification was favoured over DNRA, while DNRA was systematically more important than denitrification at higher $\mathrm{O}_{2}$ levels. Our results thus demonstrate that $\mathrm{O}_{2}$ is an important regulator of the partitioning between $\mathrm{N}$ loss and $\mathrm{N}$ recycling in sediments. In natural environments, where $\mathrm{O}_{2}$ concentrations change in near-bottom waters on an annual scale (e.g., overturning lakes with seasonal anoxia), a
\end{abstract}

marked seasonality with regards to internal $\mathrm{N}$ eutrophication versus efficient benthic fixed-N elimination can be expected.

\section{Introduction}

Over the last decades, intensive human activities have dramatically affected the nitrogen $(\mathrm{N})$ cycle in aquatic systems through elevated inputs of reactive (biologically available) $\mathrm{N}$. In some lakes, external $\mathrm{N}$ loading can lead to excessive algal blooms in the upper water column, and the subsequent decomposition of the sinking algal biomass is often associated with $\mathrm{O}_{2}$ depletion in the deeper water column and possibly seasonal or permanent anoxia (e.g. Blees et al., 2014; Lehmann et al., 2004, 2015). Depending on the $\mathrm{O}_{2}$ concentrations in the water column, and the reactivity of the sediment organic matter, the oxygen penetration depth within lacustrine sediments can vary (e.g. Lehmann et al., 2009) and so will the transition zone that separates aerobic from anaerobic biogeochemical reactions. Under oxygen-depleted conditions, both in the water column and in sediments, anaerobic $\mathrm{N}$ transformation processes such as denitrification, anammox and/or dissimilatory nitrate reduction to ammonium (DNRA) become important. While denitrification and anammox can mitigate excessive $\mathrm{N}$ loading (eutrophication) by converting reactive nitrogen $\left(\mathrm{NO}_{3}^{-}, \mathrm{NO}_{2}^{-}, \mathrm{NH}_{4}^{+}\right)$to $\mathrm{N}_{2}$, which subsequently returns to the atmosphere, DNRA retains a bioavailable form of nitrogen within the ecosystem, fostering internal eutrophication of lakes (Tiedje, 1988). 
The biogeochemical conditions that regulate the partitioning between these different $\mathrm{N}$-transforming processes (and others) in benthic environments remain uncertain, but links to other biogeochemical cycles are likely an important factor. It is commonly accepted that when organic matter and nitrate concentrations are relatively high, nitrate is mostly reduced to $\mathrm{N}_{2}$ by denitrifying bacteria (Gruber, 2008; Seitzinger et al., 2006; Seitzinger, 1988). In contrast, DNRA seems to be favoured in sediments with an excess of electron donors (total organic carbon (TOC), $\mathrm{H}_{2} \mathrm{~S}, \mathrm{Fe}^{2+}$ ) relative to nitrate (Brunet and Garcia-Gil, 1996; Roberts et al., 2014). In organic matter-rich lake sediments, the contribution of anammox to the total fixed- $\mathrm{N}$ transformation fluxes across the sediment-water interface is most likely minor relative to both denitrification and DNRA since anammox seems to occur primarily in sediments with low organic matter content (Babbin et al., 2014; Thamdrup and Dalsgaard, 2002).

Changes in the redox zonation may have a profound impact on the benthic N cycle (Otte et al., 1996). Seasonal cycles of water column mixing and stagnation can modulate the penetration of redox boundaries into the sediments, potentially changing the redox environments of, for example, nitrifiers, denitrifiers, anammox and DNRA bacteria. Oxygen can thus be considered a key regulator of benthic $\mathrm{N}$ exchange (Glud, 2008; Tiedje, 1988), and its effects are multifold. On the one side, increasing $\mathrm{O}_{2}$ concentrations may expand the oxic-suboxic zone where nitrification can supply $\mathrm{NO}_{3}^{-}$and $\mathrm{NO}_{2}^{-}$for denitrification and anammox, enhancing the overall fixed-N loss (Lehmann et al., 2015). On the other side, $\mathrm{O}_{2}$ can inhibit nitrate/nitrite reduction. When surface sediments are oxygenated, the facultative anaerobic microbes will preferably use oxygen, as the heterotrophic respiration with $\mathrm{O}_{2}$ yields more energy to cells for growth than with other oxidants (i.e., $\mathrm{NO}_{3}^{-}, \mathrm{NO}_{2}^{-}$; Froelich et al., 1979; Payne et al., 2009; Thauer et al., 1977). Moreover, under oxygenated conditions, the synthesis and/or the activity of the key enzymes involved in nitrate/nitrite reduction may be suppressed (Körner and Zumft, 1989; Baumann et al., 1996; Dalsgaard et al., 2014). Existing reports on $\mathrm{O}_{2}$ tolerance and inhibition of denitrification and anammox in environments differ quite significantly. Inhibition may occur already at very low (nanomolar) $\mathrm{O}_{2}$ concentrations (Dalsgaard et al., 2014), but experimental studies also revealed that relatively high $\mathrm{O}_{2}$ levels may be required (up to $16 \%$ saturation levels) to induce a $50 \%$ inhibition of anammox (Jensen et al., 2008; Kalvelage et al., 2011). The apparent persistence of denitrification at relatively high $\mathrm{O}_{2}$ concentration levels led to a revision of the classical paradigm regarding the absolute $\mathrm{O}_{2}$ inhibition of nitrate reduction in nature (Tiedje et al., 1988), with important implications regarding the total volume of hypoxic zones in the ocean or in lakes that hosts microbial $\mathrm{N}_{2}$ production (Paulmier and Ruiz-Pino, 2009).

While oxygen inhibition/tolerance of denitrification and anammox has been studied previously in the ocean water column (Jensen et al., 2008; Kalvelage et al., 2011; Babbin et al., 2014; Dalsgaard et al., 2014), investigations into the $\mathrm{O}_{2}$ control on benthic $\mathrm{N}$ reduction are rather rare and limited to sandy and low-organic-matter marine sediments (Gao et al., 2010; Jäntti and Hietanen, 2012; Rao et al., 2007). Despite intensified research, the exact $\mathrm{O}_{2}$ thresholds with regards to the direct inhibition of benthic $\mathrm{N}$ reduction are still poorly constrained. This is particularly true for DNRA. Recent work has highlighted the significance of DNRA even in the presence of relatively high $\mathrm{O}_{2}$ concentrations (i.e., at hypoxic levels (i.e., $10-62 \mu \mathrm{mol} \mathrm{L}^{-1}$ ) or concentrations even greater than $62 \mu \mathrm{mol} \mathrm{L}^{-1}$ ) in estuarine sediments (Roberts et al., 2012, 2014) and marine sediments (Jäntti and Hietanen, 2012), but a systematic investigation of how DNRA is impacted at low micromolar $\mathrm{O}_{2}$ levels in aquatic sediments (and how in turn the balance between denitrification and DNRA is affected) does, to our knowledge, not exist.

In this study, we provide first experimental evidence for direct $\mathrm{O}_{2}$ control on the fate of reactive $\mathrm{N}$ in lacustrine sediments with high organic matter content. Through slurry incubation experiments with sediment from a eutrophic lake in Switzerland (Lake Lugano), ${ }^{15} \mathrm{~N}$-labelled substrates and manipulated $\mathrm{O}_{2}$ concentrations, we investigated the functional response of benthic $\mathrm{N}$-reducing processes to changing $\mathrm{O}_{2}$ levels. We demonstrate that denitrification and DNRA are differentially sensitive towards $\mathrm{O}_{2}$, which has important implications for fixed-N removal in environments that undergo short- and longer-term $\mathrm{O}_{2}$ changes, such as seasonally stratified (anoxic) lakes or other aquatic environments with expanding volumes of hypoxia and anoxia.

\section{Sampling site, materials and methods}

\subsection{Sampling location}

Sediment sampling took place in the south basin of Lake Lugano, a natural alpine lake situated at the border between Switzerland and Italy. Between April and January, the water column of the basin is stratified, with bottom-water suboxia/anoxia starting in late spring/early summer (e.g., Lehmann et al., 2004, 2015). During winter February/March the lake turns over and bottom waters are oxygenated until the water column re-stratifies in spring and bottom-water $\mathrm{O}_{2}$ concentrations decrease again (Fig. 1). Water column $\mathrm{O}_{2}$ and $\mathrm{N}$ compound $\left(\mathrm{NO}_{3}^{-}, \mathrm{NO}_{2}^{-}, \mathrm{NH}_{4}^{+}\right)$concentrations were measured as part of a long-term monitoring campaign promoted by the international commission for the protection of Italian-Swiss waters (CIPAIS; Commissione Internazionale per la Protezione delle Acque Italiano-Svizzere) and run by SUPSI (University of Applied Sciences and Arts of Southern Switzerland) on behalf of the administration of the canton Ticino. Sediment cores were taken at two locations, Figino $\left(8^{\circ} 53^{\prime} 37^{\prime \prime} \mathrm{E}, 45^{\circ} 57^{\prime} 31^{\prime \prime} \mathrm{N}, 94 \mathrm{~m}\right.$ depth) and Melide $\left(8^{\circ} 57^{\prime} 29^{\prime \prime} \mathrm{E}, 45^{\circ} 56^{\prime} 22^{\prime \prime} \mathrm{N}, 85 \mathrm{~m}\right.$ depth), in October 2017, using a small gravity corer (inner diameter $6.2 \mathrm{~cm}$ ). Figure 1 

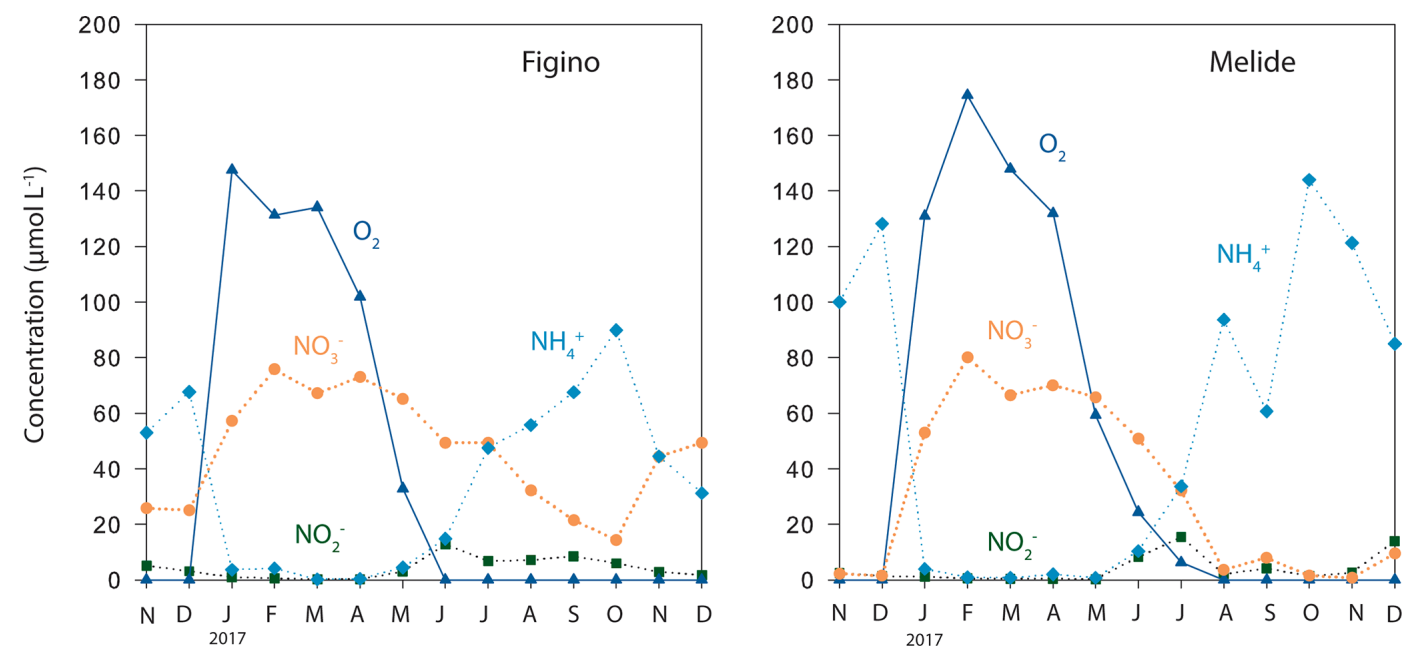

Figure 1. Concentrations of dissolved $\mathrm{O}_{2}$ and reactive nitrogen in the bottom waters ( $2 \mathrm{~m}$ above the sediments) of the Lake Lugano south basin in 2017.

displays representative seasonal trends in the deep south basin. During oxygenation of the bottom waters, nitrate concentrations in the water $2 \mathrm{~m}$ above the sediments reach about $75 \mu \mathrm{mol} \mathrm{L}^{-1}$, and even during water column anoxia nearsediment nitrate concentrations rarely dropped below 15 and $5 \mu \mathrm{mol} \mathrm{L}{ }^{-1}$ at Figino and Melide, respectively (Fig. 1; SUPSI data), so that the sediments are constantly exposed to nitratecontaining bottom waters. Ammonium concentrations in bottom water were relatively high $\left(\sim 30-140 \mu \mathrm{mol} \mathrm{L}^{-1}\right)$ during anoxia and close to the detection limit during months when the water column was mixed.

\subsection{Porewater sampling}

Porewater oxygen microprofiles were generated using an $\mathrm{O}_{2}$ microsensor (Unisense) with a tip diameter of $100 \mu \mathrm{m}$ in duplicate cores from both sites. The overlying water was gently stirred (without disturbing the sediment-water interface) and aerated to determine the $\mathrm{O}_{2}$ penetration depth under oxygenated conditions at room temperature $\left(\sim 20^{\circ} \mathrm{C}\right)$. Porewater samples for the analysis of dissolved inorganic nitrogen concentrations were obtained by sectioning of a separate set of cores from the same sites at $1 \mathrm{~cm}$ intervals under normal atmosphere and at room temperature $\left(\sim 20^{\circ} \mathrm{C}\right)$, and centrifuging of the samples were carried out ( $4700 \mathrm{rpm}, 10 \mathrm{~min})$.

\subsection{N transformation incubation experiments}

In a first step, incubations to measure potential denitrification and DNRA rates under control (i.e., anoxic) conditions were performed in an anaerobic chamber $\left(\mathrm{N}_{2}\right.$ atmosphere). At each site, fresh surface sediments (upper $2 \mathrm{~cm}$ ) from duplicate sediment cores were homogenized to prepare dilute sediment slurries. Aliquots of $1 \mathrm{~g}$ of sediment and $70 \mathrm{~mL}$ of anoxic artificial lake water $\left(\mathrm{NO}_{3}^{-}, \mathrm{NO}_{2}^{-}, \mathrm{NH}_{4}^{+}\right.$-free; Smith et al., 2002) were transferred into $120 \mathrm{~mL}$ serum bottles.
The use of dissolved- $\mathrm{NO}_{x}$-free artificial water is important to avoid any potential underestimation of $\mathrm{N}$ transformation process rates due to ${ }^{28} \mathrm{~N}_{2}$ production from ambient $\mathrm{NO}_{3}^{-}$or $\mathrm{NO}_{2}^{-}$present in bottom waters. Serum bottles were sealed and crimped using blue butyl rubber stoppers and aluminium caps. The sediment slurries (generally in triplicates, Table 1) were He-flushed for $10 \mathrm{~min}$ to lower the atmospheric $\mathrm{N}_{2}$ and $\mathrm{O}_{2}$ backgrounds and placed overnight on a shaker $(80 \mathrm{rpm})$ at $8{ }^{\circ} \mathrm{C}$ in the dark to remove any residual $\mathrm{O}_{2}$. It needs to be noted that this He-flushing step, although crucial in our experimental set-up, may have interfered with in situ conditions by altering microbe-particle interactions through disruption of larger aggregates in the sediments or by slightly changing the $\mathrm{pH}$ in the sediment slurries. Labelled ${ }^{15} \mathrm{~N}$ substrate (i.e., $\mathrm{Na}^{15} \mathrm{NO}_{3}^{-}, 99 \%{ }^{15} \mathrm{~N}$, Cambridge Isotopes Laboratories, $120 \pm 2 \mu \mathrm{mol} \mathrm{L}^{-1}$ final conc.) was added in order to quantify potential rates of denitrification and DNRA. During the incubation period (ca. $10 \mathrm{~h}$ ), anoxic sediment slurries were kept in an incubator on an orbital shaker $\left(80 \mathrm{rpm}, 8^{\circ} \mathrm{C}\right)$ in the dark. Preliminary tests were performed in order to assess the minimal incubation time required to obtain clear and robust ${ }^{15} \mathrm{~N}-\mathrm{N}_{2}$ production trends, and during which it was feasible to maintain a more or less constant $\mathrm{O}_{2}$ concentration in parallel slurry experiments. For subsampling of gas and liquid samples, the incubation vials were transferred to an anaerobic chamber with $\mathrm{N}_{2}$ atmosphere. There, $2 \mathrm{~mL}$ gas samples were taken at four successive time points $\left(T_{0}, T_{1}, T_{2}\right.$, $T_{3}$ ) for $\mathrm{N}_{2}$ isotope measurement, in exchange with $2 \mathrm{~mL} \mathrm{He}$ $\left(T_{0}\right)$ or anoxic Milli-Q water ( $T_{1}$ to $T_{3}$ ) in order to compensate for any pressure decrease inside the vials. Gas samples were then transferred into $3 \mathrm{~mL}$ exetainers (Labco), prefilled with anoxic water, and stored upside down until isotope analysis. Liquid samples $(6 \mathrm{~mL})$ were taken at $T_{0}$ and $T_{3}$ for the quantification of DNRA rates through $\mathrm{N}-\mathrm{NH}_{4}^{+}$isotope analysis (see below) and for the assessment of nutrient $\left(\mathrm{NO}_{3}^{-}\right.$, 
$\left.\mathrm{NO}_{2}^{-}, \mathrm{NH}_{4}^{+}\right)$concentrations. Samples were filtered $(0.2 \mu \mathrm{m})$ inside the anaerobic chamber prior to freezing.

\section{$2.4 \mathrm{O}_{2}$ manipulation experiments}

For the $\mathrm{O}_{2}$ manipulation experiments, serum bottles were equipped with TRACE oxygen sensor spots (TROXSP5, detection limit $=6 \mathrm{nmol} \mathrm{L}^{-1} \mathrm{O}_{2}$, Pyroscience, Germany), allowing non-invasive, contactless monitoring of dissolved $\mathrm{O}_{2}$ concentrations in the dilute slurry. The sensor spots were fixed at the inner side of the glass wall with silicone glue and the sensor signal was read out from outside using a Piccolo2 fibre-optic oxygen meter (PyroScience). Different volumes of pure $\mathrm{O}_{2}(99995 \%)$ were injected into the headspace of preconditioned and ${ }^{15} \mathrm{NO}_{3}^{-}$-amended slurries using a glass syringe (Hamilton). For each treatment, the gas volume required to reach the targeted $\mathrm{O}_{2}$ equilibrium concentration $\left(0.8,1.2,2, \ldots, 78.6 \mu \mathrm{mol} \mathrm{L}^{-1}\right)$ was calculated based on the headspace versus slurry volumes, salinity and temperature (Garcia and Gordon, 1992). Measured $\mathrm{O}_{2}$ concentrations in slurries after injection of the respective $\mathrm{O}_{2}$ gas volumes were always close to the ones calculated (the first measurement was performed $30 \mathrm{~min}$ after injection to ensure gas equilibration between the gas and the liquid phases). Oxygen concentrations in the slurry incubations were monitored with the fibre-optic oxygen meter every $30 \mathrm{~min}$ and, in the case of a decline in dissolved $\mathrm{O}_{2}$ due to microbial consumption, $\mathrm{O}_{2}$ was added in order to return to the initial target $\mathrm{O}_{2}$ concentrations (Table S1 in the Supplement). In addition to continuous agitation on the shaking table, the dilute slurries were vigorously shaken by hand every $30 \mathrm{~min}$ to avoid the formation of anoxic microniches, which may act to increase rates of anaerobic $\mathrm{N}$ transformation processes (Kalvelage et al., 2011).

\subsection{Hydrochemical analyses}

Nitrite concentrations were determined colorimetrically using sulfanilamide and Griess reagent, according to Hansen and Koroleff (1999). Total $\mathrm{NO}_{x}$ (i.e., $\mathrm{NO}_{3}^{-}+\mathrm{NO}_{2}^{-}$) concentrations were measured using a $\mathrm{NO}_{x}$ analyser (Antek model 745 , detection limit $=0.02 \mu \mathrm{mol} \mathrm{L}^{-1}$ ), by reduction to nitric oxide (NO) in an acidic $V^{3+}$ solution and quantification of the generated $\mathrm{NO}$ by chemiluminescence detection (Braman and Hendrix, 1989). Nitrate concentrations were then calculated from the difference between $\mathrm{NO}_{x}$ and $\mathrm{NO}_{2}^{-}$ concentrations. Ammonium was measured by suppressionion chromatography with conductivity detection (940 Professional IC Vario, Metrohm, Switzerland).

\section{$2.6 \quad{ }^{15} \mathrm{~N}$-based rate measurements}

For the determination of denitrification rates, gas samples from the ${ }^{15} \mathrm{~N}$-isotope enrichment experiments were analysed for ${ }^{15} \mathrm{~N} /{ }^{14} \mathrm{~N}$ isotope ratios in the $\mathrm{N}_{2}$ using a DELTA $\mathrm{V}$ Advantage isotope ratio mass spectrometer (IRMS; Thermo
Fisher Scientific) with a ConFlo IV interface (Thermo Fisher Scientific). Denitrification (and negligible anammox) rates were calculated based on the quantification of ${ }^{15} \mathrm{~N}$ in the $\mathrm{N}_{2}$ gas in excess of the natural abundance, i.e. by calculating the linear regression of ${ }^{30} \mathrm{~N}_{2}$ concentrations (and to a minor extent ${ }^{29} \mathrm{~N}_{2}$ ) over incubation time (Nielsen, 1992; Thamdrup and Dalsgaard, 2002; Fig. S1 in the Supplement). DNRA rates were quantified using the isotope-pairing method described by Risgaard-Petersen et al. (1995). Briefly, $2 \mathrm{~mL}$ liquid samples were transferred into $6 \mathrm{~mL}$ exetainers (Labco) and closed with plastic screw septum caps. The headspace was flushed with $\mathrm{He}$ for $2 \mathrm{~min}$ to reduce the ${ }^{28} \mathrm{~N}_{2}$ background, and $25 \mu \mathrm{L} \mathrm{mL}^{-1}$ of alkaline $(16 \mathrm{~mol} \mathrm{NaOH})$ hypobromite iodine solution $\left(3.3 \mathrm{~mol} \mathrm{~L}^{-1}\right)$ was added through the septum to convert $\mathrm{NH}_{4}^{+}$to $\mathrm{N}_{2}$ (Robertson et al., 2016). Exetainers were stored upside down and placed on a shaker $(100 \mathrm{rpm})$ for $24 \mathrm{~h}$ at room temperature. The produced $\mathrm{N}_{2}$ was then analysed by IRMS as described above. DNRA rates were determined based on the ${ }^{15} \mathrm{NH}_{4}^{+}$production with time, as calculated from the total ${ }^{15} \mathrm{~N}-\mathrm{N}_{2}$ in the hypobromitetreated samples (i.e., calculated from the excess ${ }^{29} \mathrm{~N}_{2}$ and ${ }^{30} \mathrm{~N}_{2}$ signals). The recovery of ${ }^{15} \mathrm{~N}$ label from identically treated standards was $>95 \%$.

\subsection{Statistics}

Results are presented as the mean and standard error of $n$ replicate experiments (Table 1). Correlation analyses were performed using Microsoft Excel software, and significant differences between results were verified using a Student's $t$ test $(P<0.05)$.

\section{Results}

\subsection{Porewater hydrochemistry}

The $\mathrm{O}_{2}$ microsensor profiles revealed that the $\mathrm{O}_{2}$ penetration at the two sites under aerated conditions ranged between $2.4 \mathrm{~mm}$ (Melide) and $3.7 \mathrm{~mm}$ (Figino, Fig. 2). The relatively low oxygen penetration depth is consistent with a high organic carbon content $(\sim 8 \%$, data not shown). According to the observed $\mathrm{O}_{2}$ concentration gradients at the two stations, the potential $\mathrm{O}_{2}$ flux into sediments was greater at Melide, suggesting a higher reactivity of the sedimentary organic matter. In contrast to the microsensor profiling, the sectioning-centrifuging technique was not sufficient to resolve the exact porewater nitrate concentration gradient, yet the observed nitrate concentration data across the sedimentwater interface (Fig. 2) clearly indicate that the sediments at both sites represent a sink for water column nitrate and that nitrate is consumed to completion already within the top centimetre of the sediments. In contrast, ammonium concentrations just below the sediment-water interface at Figino and Melide increased steeply from 830 and $600 \mu \mathrm{mol} \mathrm{L}{ }^{-1} \mathrm{NH}_{4}^{+}$ to 1.7 and $1.2 \mathrm{mmol} \mathrm{L}^{-1}$, respectively. 
Table 1. Overview of $\mathrm{N}$ transformation rates in $\mathrm{O}_{2}$-controlled slurry incubation experiments. Negative and positive values correspond to net $\mathrm{NO}_{3}^{-}$or $\mathrm{NH}_{4}^{+}$consumption and production over incubation time, respectively. Standard errors are indicated in brackets for $n$ replicates. Average denitrification and DNRA rates $\left(\mu \mathrm{mol} \mathrm{N} \mathrm{g}{ }^{-1}\right.$ wet sed. $\mathrm{d}^{-1}$ ) in anoxic control experiments were $0.11 \pm 0.01$ and $0.12 \pm 0.04$, respectively, at Figino; and $0.12 \pm 0.01$ and $0.11 \pm 0.01$, respectively, at Melide.

\begin{tabular}{|c|c|c|c|c|c|c|}
\hline \multirow{2}{*}{$\begin{array}{l}\text { Sampling } \\
\text { site }\end{array}$} & \multirow{2}{*}{$\begin{array}{c}\mathrm{O}_{2} \text { conc. } \\
\text { in slurry } \\
\mu \mathrm{mol} \mathrm{L}-1\end{array}$} & \multirow[t]{2}{*}{$n$} & \multicolumn{2}{|c|}{ Inhibition compared to control (\%) } & \multirow{2}{*}{$\begin{array}{r}\mathrm{NO}_{3}^{-} \\
\mu \mathrm{mol} \mathrm{N} \mathrm{g}\end{array}$} & \multirow{2}{*}{$\begin{array}{r}\mathrm{NH}_{4}^{+} \\
\text {wet sed. } \mathrm{d}^{-1}\end{array}$} \\
\hline & & & Denitrification & DNRA & & \\
\hline \multirow[t]{12}{*}{ Figino } & 0 (control) & & & & $-1.4(0.1)$ & $0.7(0.03)$ \\
\hline & 1.2 & 12 & 29 & 51 & $-0.8(0.2)$ & $0.8(0.4)$ \\
\hline & 2 & 3 & 57 & 35 & $-0.4(0.1)$ & $0.8(0.2)$ \\
\hline & 2.8 & 3 & 68 & 17 & $-0.4(0.3)$ & $0.7(0.1)$ \\
\hline & 3.4 & 2 & 64 & 29 & $-0.6(0.2)$ & $0.6(0.1)$ \\
\hline & 4.1 & 3 & 77 & 45 & $-0.9(1.3)$ & $0.5(0.2)$ \\
\hline & 8.6 & 3 & 85 & 60 & $-1.1(0.3)$ & $0.4(0.0)$ \\
\hline & 16 & 4 & 70 & 84 & $-0.2(0.5)$ & $0.1(0.2)$ \\
\hline & 24.1 & 3 & 86 & 77 & $-0.2(0.6)$ & $0.2(0.1)$ \\
\hline & 38 & 3 & 93 & 39 & $0.2(2.1)$ & $0.0(0.2)$ \\
\hline & 61.3 & 3 & 94 & 64 & $-0.3(0.3)$ & $-0.2(0.1)$ \\
\hline & 78.6 & 6 & 96 & 79 & $1.1(1.4)$ & $-0.1(0.0)$ \\
\hline \multirow[t]{12}{*}{ Melide } & 0 (control) & 9 & & & $-1.0(0.4)$ & $0.2(0.0)$ \\
\hline & 0.8 & 2 & 43 & 37 & $-0.7(0.2)$ & $-0.1(0.1)$ \\
\hline & 1.8 & 2 & 63 & 53 & $-0.6(0.1)$ & $0.2(0.2)$ \\
\hline & 2.9 & 3 & 61 & 58 & $-0.5(0.3)$ & $-0.1(0.2)$ \\
\hline & 3.8 & 4 & 58 & 65 & $-0.2(0.1)$ & $-0.1(0.3)$ \\
\hline & 4.9 & 3 & 74 & 64 & $-0.3(0.2)$ & $-0.1(0.3)$ \\
\hline & 9 & 7 & 73 & 69 & $0.0(0.1)$ & $-0.1(0.2)$ \\
\hline & 13.1 & 2 & 69 & 37 & $-0.6(0.1)$ & $-0.1(0.0)$ \\
\hline & 21.3 & 2 & 66 & 56 & $-0.4(0.1)$ & $-0.1(0.1)$ \\
\hline & 44.4 & 2 & 67 & 34 & $-0.3(0.2)$ & $-0.1(0.2)$ \\
\hline & 58.6 & 3 & 91 & 60 & $-0.1(0.1)$ & $-0.1(0.2)$ \\
\hline & 73.2 & 4 & 93 & 75 & $0.2(0.2)$ & $-0.4(0.1)$ \\
\hline
\end{tabular}

\section{2 $\mathrm{N}$ transformations in control experiments}

Potential rates of denitrification and DNRA under true anoxic conditions were quantified at both sampling sites in October 2017. Anammox rates were measured in a previous study at different times of the year, and their contribution to the total fixed-N removal was always less than $1 \%$, thus negligible with respect to other processes (Cojean et al., 2019). Indeed, in all experiments, denitrification and DNRA were the main benthic $\mathrm{N}$ transformation processes with an essentially equal contribution to the total nitrate reduction $(\approx$ $0.1 \mu \mathrm{mol} \mathrm{N} \mathrm{g}^{-1}$ wet sed. $\mathrm{d}^{-1}$; Table 1 caption). We ensured that measured DNRA rates were not underestimated due to ${ }^{15} \mathrm{NH}_{4}^{+}$loss through adsorption on mineral surfaces. Previous results (Cojean et al., 2019) demonstrate that adsorption of ambient or tracer ammonium does not occur at detectable levels in the dilute sediment slurries. Ammonium consumption by nitrifiers in the presence of $\mathrm{O}_{2}$, however, might slightly affect quantification of DNRA rates. Indeed, oxic slurry incubation experiments $\left(\geq 73 \mu \mathrm{mol} \mathrm{L}^{-1} \mathrm{O}_{2}\right)$ re- vealed that at least at high $\mathrm{O}_{2}$ concentrations net $\mathrm{NO}_{3}^{-}$production occurs $\left(\leq 1 \mu \mathrm{mol} \mathrm{N} \mathrm{g}{ }^{-1}\right.$ wet sed. $\left.\mathrm{d}^{-1}\right)$.

\subsection{Impact of $\mathrm{O}_{2}$ on $\mathrm{NO}_{3}^{-}$reduction in sediments}

The $\mathrm{O}_{2}$ sensitivity of denitrification and DNRA and inhibition kinetics were investigated through slurry incubation experiments under $\mathrm{O}_{2}$-controlled conditions. At both sites, potential denitrification and DNRA rates consistently decreased with increasing $\mathrm{O}_{2}$ concentration (Fig. 3). While the general pattern was systematic for both processes (i.e., an exponential attenuation of both denitrification and DNRA rates with increasing $\mathrm{O}_{2}$ ), the response of denitrifiers versus nitrate ammonifiers to manipulated $\mathrm{O}_{2}$ differed across sites and treatments. We compared $\mathrm{O}_{2}$-addition experiments to the anoxic controls to estimate the inhibition of nitrate reduction by $\mathrm{O}_{2}$. At the lowest $\mathrm{O}_{2}$ concentration $\left(\sim 1 \mu \mathrm{mol} \mathrm{L}{ }^{-1} \mathrm{O}_{2}\right)$, denitrification was less inhibited than DNRA at Figino $(29 \pm 20 \%$ and $51 \pm 7 \%$ inhibition, respectively) while the suppression was almost equivalent at Melide $(43 \pm 8 \%$ and $37 \pm 9 \%$ inhibition of denitrification and DNRA, respectively; Table 1). 

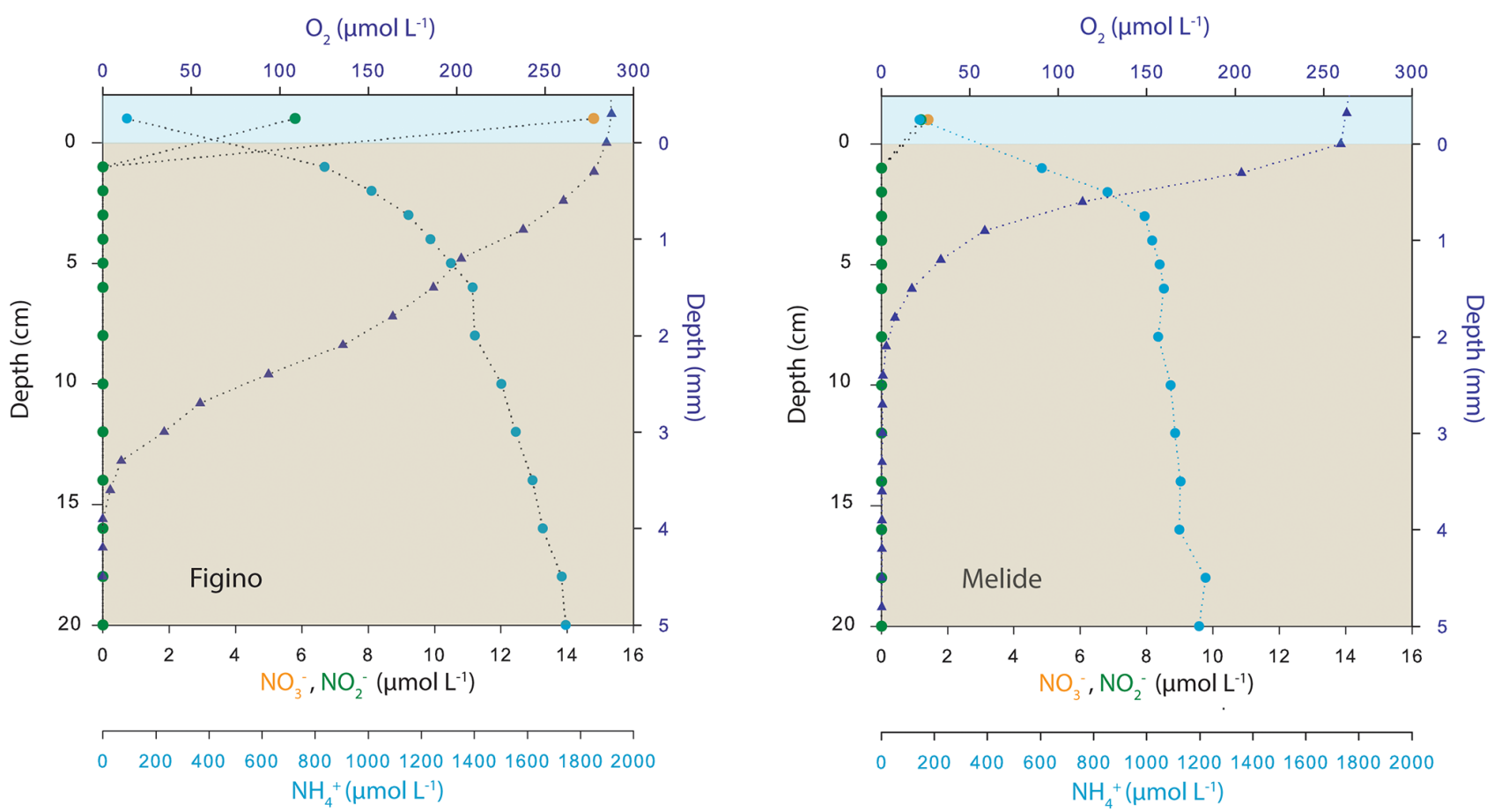

Figure 2. Ex situ sediment porewater profiles $\left(\mathrm{O}_{2}\right.$ and dissolved inorganic nitrogen) at the two sampling stations of the Lake Lugano south basin in sediment cores collected in October 2017. Symbols correspond to the mean value of $\mathrm{O}_{2}$ (triangles) and dissolved $\mathrm{N}$ species (circles) concentrations measured in triplicate and duplicate cores, respectively. Oxygen concentration profiles (note different depth units) were determined in aerated cores and thus are representative of the $\mathrm{O}_{2}$ penetration during aerated conditions in the water column, as seen between January and April (see Fig. 1).

At $\mathrm{O}_{2}$ concentrations around $2 \pm 0.2 \mu \mathrm{mol} \mathrm{L}{ }^{-1}$, both denitrification and DNRA rates were more than $50 \%$ inhibited compared to the anoxic control (Table 1, Fig. 3). At $\mathrm{O}_{2}$ concentration $\geq 2 \mu \mathrm{mol} \mathrm{L}^{-1}$, DNRA rates were generally higher than those of denitrification (with one exception, i.e., $16 \mu \mathrm{mol} \mathrm{L}-1$ $\mathrm{O}_{2}$ at Figino; Fig. 3), indicating that denitrification was more sensitive than DNRA to elevated $\mathrm{O}_{2}$ levels. Oxygen concentrations higher than $73 \mu \mathrm{mol} \mathrm{L}{ }^{-1}$ resulted in almost complete inhibition of denitrification at both sites $(96 \pm 1 \%$ and $93 \pm 2 \%$ at Figino and Melide, respectively; Table 1). Oxygen inhibition thresholds for DNRA were even higher, as DNRA rates were significantly less impaired compared to denitrification at these elevated $\mathrm{O}_{2}$ levels $(79 \pm 5 \%$ and $75 \pm 4 \%$ inhibition compared to the anoxic controls at Figino and Melide, respectively; Table 1). A correlation analysis between the relative contribution of DNRA to the total $\mathrm{NO}_{3}^{-}$reduction $(\%)$ and the increase in $\mathrm{O}_{2}$ concentration displayed a positive correlation coefficient of 0.57 and 0.91 for Figino and Melide, respectively (Fig. S2). Hence, the relative contribution of the two processes to total nitrate reduction was significantly affected by changing $\mathrm{O}_{2}$ concentrations. At anoxic and sub-micromolar levels of $\mathrm{O}_{2}\left(\leq 1 \pm 0.2 \mu \mathrm{mol} \mathrm{L}^{-1} \mathrm{O}_{2}\right)$, denitrification rates were higher than those of DNRA, while at higher $\mathrm{O}_{2}$ concentration the ratio between denitrification and DNRA was shifted in favour of the nitrate ammonifiers (Fig. 4).

Consistent with the observed decline in denitrification and DNRA rates based on the ${ }^{15} \mathrm{~N}-\mathrm{N}_{2}$ and ${ }^{15} \mathrm{NH}_{4}^{+}$measurements in the ${ }^{15} \mathrm{~N}$-label incubations, nitrate consumption in slurries decreased with increasing $\mathrm{O}_{2}$ concentration at both stations (Table 1). Similarly, maximum ammonium accumulation was observed in the anoxic controls, whereas at higher $\mathrm{O}_{2}$ levels ammonium underwent net consumption, indicating the concomitant decrease in DNRA and the increasing importance of nitrification under more oxic conditions, particularly at Melide. In incubations where nitrate concentrations decreased, the ratio of $\left(\mathrm{NO}_{3}^{-}\right)_{\text {consumed }}:\left({ }^{15} \mathrm{~N}\right.$ $\mathrm{N}_{2}+{ }^{15} \mathrm{NH}_{4}^{+}$) produced was always significantly higher $(>5$ : $1)$ than expected $(1: 1)$. This observation is consistent with previous work in the Lake Lugano south basin (Wenk et al., 2014). Here, whole-core flow-through incubations also revealed that $\mathrm{NO}_{3}^{-}$fluxes into the sediments significantly exceeded benthic $\mathrm{N}_{2}$ production, an imbalance, which could be explained by neither nitrate reduction to ammonium nor incomplete reduction to $\mathrm{N}_{2} \mathrm{O}$. As it is not the scope of this study, we will not discuss this puzzling discrepancy further, but we speculate that excess $\mathrm{NO}_{3}^{-}$consumption may be linked to bacterial and algal uptake (Bowles et al., 2012). Biotic immobilization of $\mathrm{NO}_{3}^{-}$in marine sediments has been 
attributed previously to the intracellular storage of nitrate by filamentous bacteria (Prokopenko et al., 2013; Zopfi et al., 2001) and/or diatoms (Kamp et al., 2011), but we do not know yet whether such nitrate sinks are also important in Lake Lugano sediments.

\section{Discussion}

\subsection{Anaerobic N cycling in the south basin of Lake Lugano}

Benthic denitrification and DNRA were the predominant anaerobic $\mathrm{N}$ transformation processes at the two studied stations. Interestingly, the contribution of DNRA was systematically higher than observed in flow-through whole-core incubations performed with sediment from the same basin. Wenk et al. (2014) reported a maximum DNRA contribution to $\mathrm{NO}_{3}^{-}$reduction of not more than $12 \%$, but they also argued that their DNRA rate measurements must be considered conservative because they did not account for the production of ${ }^{14} \mathrm{NH}_{4}^{+}$from ambient natural-abundance nitrate. The reason for such a discrepancy is unclear, but there seems to be a tendency for slurry incubations to yield higher DNRA rates compared to denitrification (Kaspar, 1983), implying biasing methodological effects. The observed discrepancies may also be related to natural sediment heterogeneity and/or seasonal/interannual fluctuations in benthic $\mathrm{N}$ transformation rates. As for the latter, in 2016, the annual water overturn and bottom-water ventilation was exceptionally suspended and sediments remained anoxic for more than a year. In contrast, in 2017, the water column mixed in January and surface sediments were oxygenated throughout June. Our $\mathrm{O}_{2}$ manipulation experiments revealed that redox conditions have a marked impact on the partitioning between the two nitrate reduction pathways, and consistent with the slurry incubation data the extended $\mathrm{O}_{2}$ exposure of microbes at the sediment-water interface in 2017 compared to the preceding year may have favoured nitrate ammonifiers over denitrifiers. Independent of any possible spatio-temporal variability, in this study, DNRA rates were equal to, or even higher than, denitrification. Such a partitioning of the two nitrate-reducing processes is not implausible and was similarly observed in a wide range of environments, particularly in more reduced sediments with high organic matter content and comparatively low nitrate levels (Brunet and Garcia-Gil, 1996; Dong et al., 2011; Papaspyrou et al., 2014). More generally, substrate-availability changes induced by $\mathrm{O}_{2}$ fluctuations may be important drivers of the partitioning between denitrification and DNRA (Cojean et al., in prep.), and environmental conditions that favour DNRA over denitrification may be quite common. However, to our knowledge, experimental evidence for the direct $\mathrm{O}_{2}$ control on the balance between these two nitrate-reducing processes is still lacking.

\section{2 $\mathrm{O}_{2}$ inhibition thresholds of benthic nitrate reduction}

Our study shows that sub-micromolar $\mathrm{O}_{2}$ levels significantly lowered both denitrification and DNRA rates. Denitrification and DNRA were inhibited by about 30\%-50\% at $1 \mu \mathrm{mol} \mathrm{L}-1 \mathrm{O}_{2}$, while in previous studies that investigated $\mathrm{O}_{2}$ effects on fixed-N elimination in the water column, denitrification was almost completely suppressed at this $\mathrm{O}_{2}$ level already. For example, by conducting incubation experiments using samples from oxygen minimum zones in the eastern tropical Pacific, a $50 \%$ inhibition of denitrification was noticed already at $0.2 \mu \mathrm{mol} \mathrm{L}^{-1} \mathrm{O}_{2}$, and complete suppression was noticed at 1.5-3 $\mathrm{mol} \mathrm{L}^{-1} \mathrm{O}_{2}$ (Dalsgaard et al., 2014; Babbin et al., 2014). Similarly, incubation experiments with samples from a Danish fjord exhibited full inhibition of denitrification at $8-15 \mu \mathrm{mol} \mathrm{L}^{-1} \mathrm{O}_{2}$ (Jensen et al., 2009). In marine sediments, in contrast, denitrification was occurring even at $\mathrm{O}_{2}$ concentrations greater than $60 \mu \mathrm{mol} \mathrm{L}{ }^{-1}$ (Gao et al., 2010; Rao et al., 2007). This is in agreement with our results showing that at higher $\mathrm{O}_{2}$ levels $\left(\geq 73 \mu \mathrm{mol} \mathrm{L}{ }^{-1}\right)$ denitrification was still active although at very low rates compared to the anoxic control ( $\geq 93 \%$ inhibition). Similarly, DNRA was still occurring and was less impaired by the elevated $\mathrm{O}_{2}$ concentration compared to denitrification $(\geq 75 \%$ inhibition relative to the anoxic control). An increase in DNRA relative to denitrification rates under oxic conditions $\left(>100 \mu \mathrm{mol} \mathrm{L} \mathrm{L}^{-1} \mathrm{O}_{2}\right)$ was also observed in estuarine sediments, though $\mathrm{N}$ removal remained predominant (Roberts et al., 2012, 2014). In brackish sediments in the Gulf of Finland in the Baltic Sea, at elevated $\mathrm{O}_{2}$ concentrations (from 50 to $110 \mu \mathrm{mol} \mathrm{L}^{-1}$ in bottom waters), benthic DNRA rates were generally higher than denitrification rates (Jäntti and Hietanen, 2012), further supporting our findings. Yet, in contrast to our study, their observations suggest a higher $\mathrm{O}_{2}$ sensitivity (i.e., greater inhibition) of DNRA compared to denitrification in sediments with higher bottom-water $\mathrm{O}_{2}$ concentrations $\left(>110 \mu \mathrm{mol} \mathrm{L}^{-1}\right)$. Given the paucity and discrepancy of existing data in this context, it is premature to conclude that DNRA microbes are generally less or more oxygen-tolerant than denitrifiers. A direct comparison of DNRA $\mathrm{O}_{2}$ inhibition thresholds in this study and in the study of Jäntti and Hietanen (2012) is difficult because of the differing methodological approaches. There, nitrate reduction rates were determined in whole-core incubations, without manipulating (and measuring) the $\mathrm{O}_{2}$ concentrations at the sediment depth where nitrate is actually reduced. And although the $\mathrm{O}_{2}$ penetration depth and porewater $\mathrm{O}_{2}$ concentrations will respond to a certain degree to the $\mathrm{O}_{2}$ content in the bottom water, deducing the actual $\mathrm{O}_{2}$ concentrations for the active nitrate reduction zone within the sediment from $\mathrm{O}_{2}$ concentrations in the overlying water is problematic. Here, we tested the oxygen sensitivity of a microbial community in suspension, directly exposed to defined $\mathrm{O}_{2}$ conditions. These incubation data indicate that DNRA is less inhibited than denitrification 

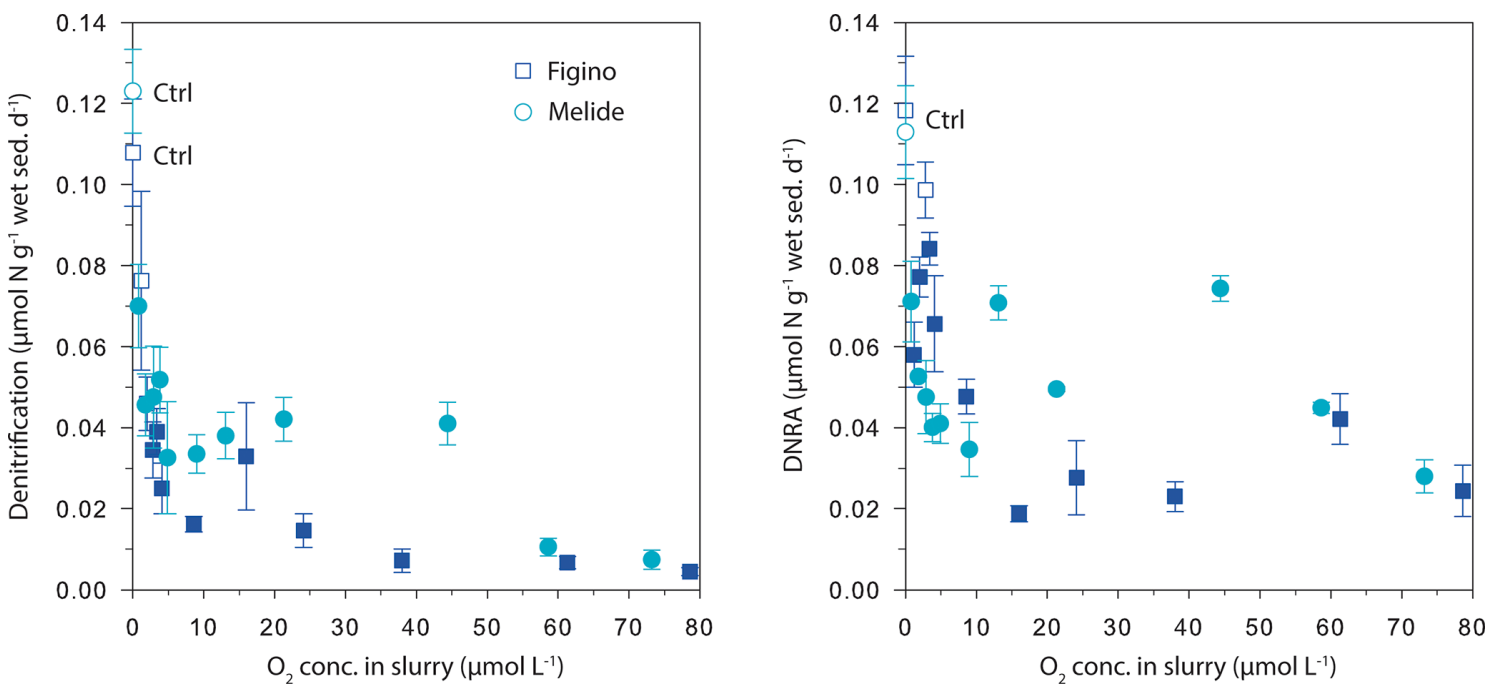

Figure 3. Denitrification and DNRA rates as a function of dissolved $\mathrm{O}_{2}$ concentration in dilute sediment slurry from Figino and Melide. Statistically significant differences between denitrification/DNRA rates measured in the different $\mathrm{O}_{2}$ treatments versus those in the respective control (Ctrl) experiments are shown by the filled symbols $(P<0.05$, Table S2). Error bars represent the standard error of $n$ replicate experiments and measurements (Table 1).
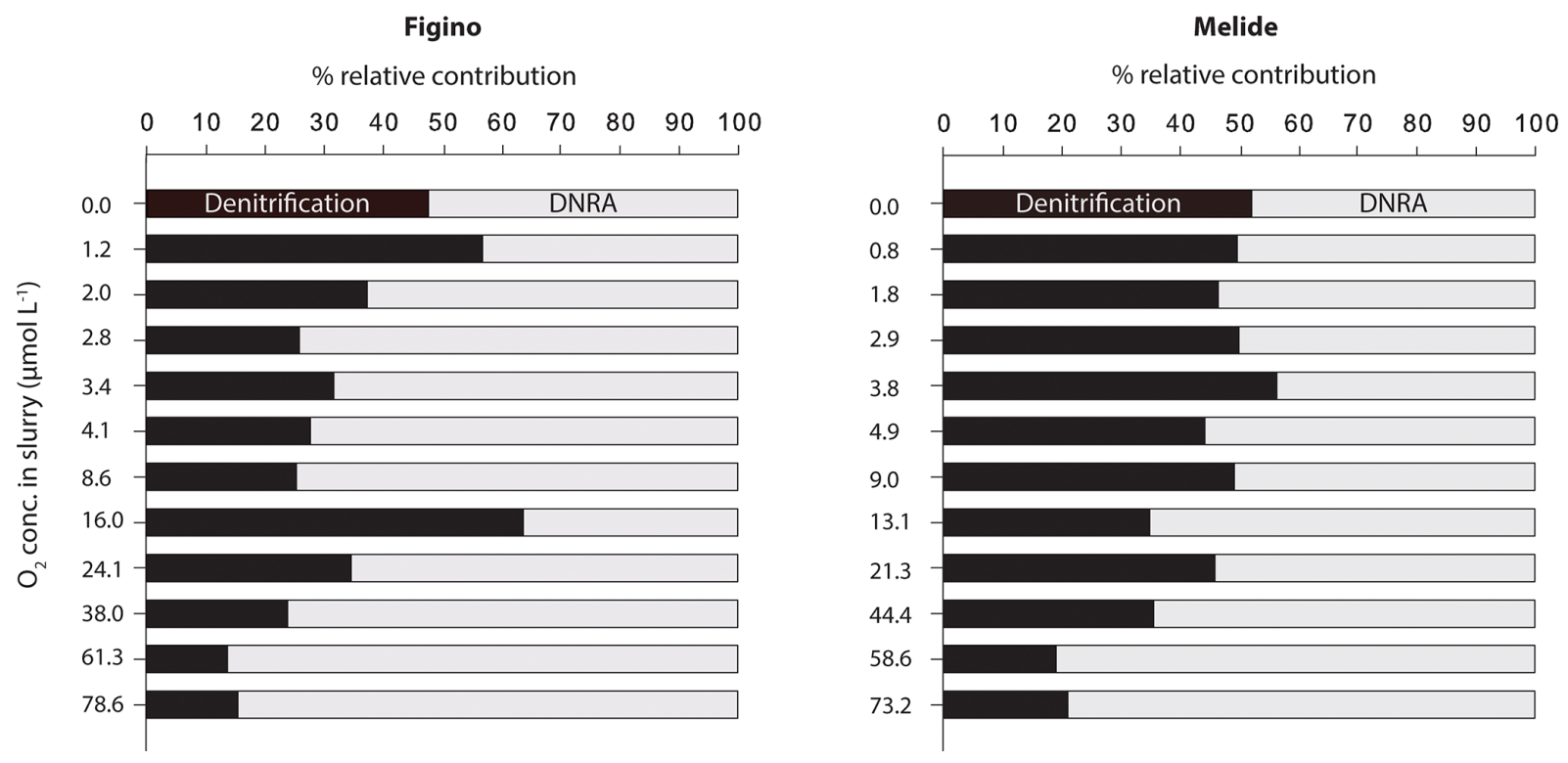

Figure 4. Relative contribution (\%) of denitrification and DNRA to total nitrate reduction under variable $\mathrm{O}_{2}$ conditions.

at $\mathrm{O}_{2}$ concentrations $\geq 73 \mu \mathrm{mol} \mathrm{L}-1$ and, at the same time, imply that anoxia per se is not a strict requirement for DNRA, as previous ecosystem-scale work has also suggested (Burgin and Hamilton, 2007). Our results are also consistent with observations made in soil microcosms showing that DNRA is less sensitive to increasing $\mathrm{O}_{2}$ partial pressures than denitrification within the range of $0 \%-2 \% \mathrm{O}_{2} v / v$ (Fazzolari et al., 1998; Morley and Baggs, 2010).

The observed $\mathrm{O}_{2}$ inhibition thresholds for nitrate reduction are significantly higher than reported from most incubation studies with water column samples (Dalsgaard et al.,
2014; Babbin et al., 2014; Jensen et al., 2008). Elevated $\mathrm{O}_{2}$ tolerance in prior studies was often attributed to the formation of anoxic microniches that may foster anaerobic $\mathrm{N}$ reduction (Kalvelage et al., 2011). It is unlikely that such microniches formed during our incubation experiments since slurries were heavily diluted ( $1 \mathrm{~g}$ sediment in $70 \mathrm{~mL}$ water) and vigorously shaken by hand every $30 \mathrm{~min}$, in addition to the continuous agitation on a shaking table during the incubation. Also, experiments were replicated two to three times for some $\mathrm{O}_{2}$-amended treatments, and measured rates were very similar between replicates. If anoxic microniches had 
formed, we would have expected their formation to be more variable, resulting in a lower reproducibility of the determined rates.

The existence of aerobic denitrifiers (i.e. microbes that reduce $\mathrm{NO}_{3}^{-} / \mathrm{NO}_{2}^{-}$to $\mathrm{N}_{2}$ in the presence of $\mathrm{O}_{2}$ ) in soils and sediments has been confirmed through isolation of bacterial strains (e.g. Robertson et al., 1995), and it was suggested that they contribute to the total fixed-N loss in marine sediments (Carter et al., 1995; Patureau et al., 2000; Zehr and Ward, 2002). Recent studies of permeable marine sediments (Gao et al., 2010) and soils (Bateman and Baggs, 2005; Morley et al., 2008) also observed significant $\mathrm{N}_{2}$ production in the presence of $\mathrm{O}_{2}$ and attributed it to aerobic denitrification

\subsection{DNRA favoured under less reducing conditions}

It is generally assumed that strongly reducing conditions favour DNRA over denitrification, yet in our study, particularly at elevated $\mathrm{O}_{2}$ concentrations, DNRA rates were higher than those of denitrification. That DNRA often seems to be more important under true anoxic conditions may therefore not be linked directly to the absence of $\mathrm{O}_{2}$ and differential $\mathrm{O}_{2}$ inhibition levels of the two nitrate-reducing processes. Indirect mechanisms are likely to be important. For instance, $\mathrm{H}_{2} \mathrm{~S}$ accumulation, which often accompanies prolonged anoxia, can inhibit denitrification and simultaneously enhance DNRA (An and Gardner, 2002; Rysgaard et al., 1996). Another indirect, redox-dependent factor may be the availability of nitrate. Higher DNRA rates were observed under more $\mathrm{NO}_{3}^{-}$-limiting conditions induced by prolonged anoxia, probably because nitrate ammonifiers are able to gain more energy per $\mathrm{NO}_{3}^{-}$molecule reduced than denitrifiers (Dong et al., 2011). As nitrate concentrations are generally much lower under oxygen-free conditions, it appears plausible that anoxia-associated nitrate and nitrite depletion is conducive to higher DNRA / denitrification rates. While these examples seem to support that DNRA is favoured under true anoxic conditions, results of other studies are more consistent with our observation of higher DNRA than denitrification rates at elevated $\mathrm{O}_{2}$ concentrations. For example, in estuarine sediments, DNRA was stimulated relative to denitrification under more oxidizing conditions (Roberts et al., 2014, 2012). The authors argued that DNRA is enhanced by increasing $\mathrm{Fe}^{2+}$ availability at the oxic-anoxic sediment layer during more oxygenated conditions. These studies highlight the importance of redox conditions in regulating the balance between denitrification and DNRA; however, to what extent $\mathrm{O}_{2}$ directly controls the partitioning between the two nitrate-reducing processes at the enzyme levels remains, to our knowledge, unknown. Apparent contradictions with regards to how changing $\mathrm{O}_{2}$ levels may impact nitrate reduction may simply be due to the counteracting and variable influence of direct versus indirect effects of the variable $\mathrm{O}_{2}$ concentrations.
We cannot fully exclude that through $\mathrm{O}_{2}$ manipulation in this study, we partly affected nitrate reduction indirectly through its control of $\mathrm{H}_{2} \mathrm{~S}$ or $\mathrm{Fe}^{2+}$. Yet, we set up the experiments in a way that indirect effects should be minimized (e.g., no free sulfide measured in any of the incubations, same organic matter content, same excess $\mathrm{NO}_{3}^{-}$concentrations), and this study can thus be considered an investigation into the direct $\mathrm{O}_{2}$ effect on the partitioning between $\mathrm{N}$ loss by denitrification and $\mathrm{N}$ recycling by DNRA in aquatic sediments. The fact that in our experiments we can essentially exclude the effects of redox-related parameter changes (i.e., $\mathrm{H}_{2} \mathrm{~S}, \mathrm{NO}_{3}^{-}$, and $\mathrm{Fe}^{2+}$ ) leads us to the conclusion that in the studied sediments from Lake Lugano, $\mathrm{O}_{2}$ likely controls the balance between denitrification and DNRA at the organism level and that denitrification is in fact more sensitive towards increasing $\mathrm{O}_{2}$ concentrations than DNRA.

\subsection{Direct $\mathrm{O}_{2}$ control on benthic $\mathrm{NO}_{3}^{-}$reduction}

It has been previously reported that $\mathrm{O}_{2}$ can either suppress the synthesis of enzymes involved (Baumann et al., 1996) or the enzyme activity itself (Dalsgaard et al., 2014). The observed DIN concentration trends (i.e. decreasing nitrate consumption) with increasing $\mathrm{O}_{2}$ concentrations suggest that the overall activity is modulated mainly at the nitrate reduction step. Without conclusive information on enzyme activities in hand, we can only speculate at this point about any real difference in $\mathrm{O}_{2}$-dependent response of the enzymes involved in denitrification versus DNRA. The differential response of denitrifiers and nitrate ammonifiers may, however, suggest a distinct $\mathrm{O}_{2}$ sensitivity of the nitrate reductase enzymes involved. Denitrifiers and nitrate ammonifiers utilize the same nitrate reductase enzymes (Nar, Nap), and while a differential $\mathrm{O}_{2}$ sensitivity of the same type of enzyme is difficult to explain, it is certainly possible for different enzymes. Indeed, the membrane-bound (Nar) and the periplasmic (Nap) nitrate reductases have distinct affinities towards $\mathrm{NO}_{3}^{-}$and $\mathrm{O}_{2}$ tolerance (Mohan and Cole, 2007). Periplasmic nitrate reduction is almost exclusively found in the Proteobacteria, and many of the organisms possess both Nar and Nap systems, whose production is regulated in response to ambient $\mathrm{NO}_{3}^{-}$and $\mathrm{O}_{2}$ concentrations (Simon and Klotz, 2013). When $\mathrm{NO}_{3}^{-}$is scarce, Nap provides a high-affinity (for $\mathrm{NO}_{3}^{-}$) but low-activity pathway that does not require $\mathrm{NO}_{3}^{-}$transport into the cell cytoplasm (Mohan and Cole, 2007). In the presence of oxygen, nitrate transport across the cell membrane is repressed, preventing nitrate reduction by the membrane-bound enzyme Nar with its cytoplasm-facing active site (Moir and Wood, 2001). In contrast, nitrate reduction in the periplasm is less $\mathrm{O}_{2}$ sensitive, so that microbes possessing and relying on Nap are likely to have an ecological advantage in environments that are subject to $\mathrm{O}_{2}$ fluctuation (Carter et al., 1995). In nature, nitrate reduction by denitrifiers is assumed to be catalysed primarily by Nar (Richard- 
son et al., 2007), while most nitrate ammonifiers seem to use Nap (Mohan and Cole, 2007).

Clearly, more fundamental research is required in environmentally relevant non-model microorganisms or mixed communities to understand better the combined effects of $\mathrm{O}_{2}$ on the nitrogen-transforming metabolic pathways and their regulation. Additional $\mathrm{O}_{2}$ inhibitory effects at one of the downcascade enzyme levels (Nir, Nrf, Nor, Nos) are likely to exhibit variable $\mathrm{O}_{2}$ sensitivities (Baumann et al., 1996, 1997; Körner and Zumft, 1989; Poock et al., 2002). While we are aware that the treatment above is speculative, we argue that our observations of higher DNRA / denitrification ratios at higher $\mathrm{O}_{2}$ provide at least putative evidence that microorganisms performing DNRA using Nap may be more $\mathrm{O}_{2}$ tolerant than denitrifiers using Nar, a hypothesis that requires further testing.

\subsection{Implication for $\mathrm{N}$ elimination versus $\mathrm{N}$ recycling in lakes with fluctuating $\mathrm{O}_{2}$ conditions}

The redox-sensitive partitioning of nitrate elimination (through $\mathrm{N}_{2}$ production by denitrification) versus fixed-N recycling (by nitrate ammonification) has likely important ecosystem-scale consequences. The annual water column turnover of holomictic lake basins such as the south basin of Lake Lugano plays an important role in regulating the contribution of $\mathrm{N}$ removal and $\mathrm{N}$ recycling in the water column (Lehmann et al., 2004; Wenk et al., 2014). To which extent $\mathrm{O}_{2}$ fluctuations affect $\mathrm{N}$ transformation reactions within the sediments remains uncertain. Winter water column turnover ventilates the bottom waters and reoxygenates surface sediments that were anoxic for several months. Hence, at least in the top millimetres of the sediment column, we can expect changes in the benthic $\mathrm{N}$ cycling. Based on our incubation experiments, the $\mathrm{O}_{2}$ inhibition threshold was lower for denitrification than for DNRA, possibly reflecting differential adaption of the in situ microbial community of denitrifiers and nitrate ammonifiers to fluctuating $\mathrm{O}_{2}$ conditions of bottom waters. Indeed, many nitrate ammonifiers possess both nitrate reductase enzymes (Nap and Nar) and can switch between the two respiratory systems, providing them with an ecological advantage over denitrifiers when substrates become limiting (i.e., with regards to the primary reductant used in energy metabolism; Mohan and Cole, 2007). During oxygenated bottom-water conditions, within the benthic redox transition zone, nitrate-reducing microbes at the sediment-water interface will be exposed to elevated $\mathrm{O}_{2}$ concentrations, similar to the ones tested here. Our experimental data imply that then, at least in the uppermost sediments, DNRA is favoured over denitrification. We may even expect an $\mathrm{O}_{2}$-regulated zonation of DNRA and denitrification. As a consequence, when denitrification-driven nitrate reduction is pushed down, it is possible that $\mathrm{NO}_{3}^{-}$will be partially consumed through DNRA before it gets to the "denitrification layer", as nitrate ammonifiers are less $\mathrm{O}_{2}$ sensitive than den- itrifiers. In contrast, denitrification is likely to be a more important nitrate-reducing process compared to DNRA during water column stratification (suboxia or anoxia in bottom waters), when the sediments are fully anoxic.

In the discussion thus far, we implicitly assume that the main control $\mathrm{O}_{2}$ exerts on the absolute and relative rates of denitrification and DNRA is due to its inhibitory effects at the organism level, yet the effect of $\mathrm{O}_{2}$ on the coupling of nitrification and nitrate reduction by either denitrification or DNRA remained unaddressed. Oxygen fluctuations in the natural environment will affect nitrate regeneration by nitrification and hence determine how much nitrate is available for microbial reduction. It has been shown previously that through oxygenation events (e.g., the increase in bottomwater $\mathrm{O}_{2}$ concentrations during episodic mixing/ventilation), the overall benthic $\mathrm{N}$ elimination in lakes may be enhanced through coupled nitrification-denitrification, at least transiently (Hietanen and Lukkari, 2007; Lehmann et al., 2015). Thus, while the direct effect of elevated $\mathrm{O}_{2}$ would be to hamper fixed-N elimination by denitrification at the organism level, the oxygenation of previously ammonium-laden but nitrate-free porewaters would help to better exploit the benthic nitrate reduction potential by increasing the nitrate availability for nitrate-reducing microbes within the sediments, so that the overall nitrate reduction may be stimulated (Lehmann et al., 2015). Yet, as shown in the present study, oxygenation of the water column and the upper surface sediments may also act to shift the balance between denitrification and DNRA towards DNRA, thus promoting $\mathrm{N}$ recycling rather than fixed-N elimination through denitrification. Total nitrification rates were not measured in this study, but nitrate concentration changes in sediment slurries suggest that at elevated $\mathrm{O}_{2}$ levels there is at least some production of nitrate. There is no obvious reason to assume that $\mathrm{O}_{2}$ stimulation of the coupling of nitrification and denitrification on the one hand and of nitrification and DNRA on the other hand would per se be different. Yet, as demonstrated here, DNRA appears to be less $\mathrm{O}_{2}$ sensitive compared to denitrification. It is thus reasonable to expect a higher coupling of nitrification with DNRA than with denitrification during oxygenated bottom-water conditions. Indeed, there is putative evidence for such an indirect link between $\mathrm{O}_{2}$ and elevated coupled nitrification-DNRA. In a recent study with estuarine sediments, stronger stimulation of DNRA compared to denitrification was observed during oxygenation of bottom waters, in parts attributed to the coupling to nitrification (Roberts et al., 2012). Additional experimental work is required to better understand the role of nitrification in regulating the balance between benthic denitrification and DNRA during oxygenation of bottom waters.

It is important to understand that in the natural environment, $\mathrm{O}_{2}$ will not be the only regulator of the balance between denitrification and DNRA. As previously mentioned, the partitioning of the two nitrate-reducing processes can also be modulated by the substrate (e.g., $\mathrm{NO}_{3}^{-}, \mathrm{NO}_{2}^{-}$, TOC, 
$\mathrm{H}_{2} \mathrm{~S}, \mathrm{Fe}^{2+}$ ) availability. The latter may be redox controlled or not. Such regulation may be linked to the differential substrate affinity of the two processes when competing for the same electron acceptor (e.g., nitrate/nitrite) providing selective pressure that can drive communities towards either denitrification or DNRA (Kraft et al., 2014), or it may be linked to differing substrate requirements in the case of chemolithotrophic versus organotrophic nitrate reduction.

For example, nitrate concentrations in the water column of the lake sampled in this study (Lake Lugano) varied significantly over the year, with very low $\mathrm{NO}_{3}^{-}$concentrations during the stagnation period (during anoxia; Fig. 1). As a consequence, it is reasonable to assume that the relative partitioning between denitrification and DNRA in a natural environment is affected by the fluctuating nitrate concentrations (e.g., Tiedje et al., 1988; Dong et al., 2011). Similarly, $\mathrm{Fe}^{2+}$ levels in near-bottom waters and sediment porewaters in Lake Lugano are greater during the anoxia (i.e. stratification) period (Lazzaretti et al., 1992). At least in environments where chemolithotrophic processes contribute to the overall nitrate reduction, such redox-dependent $\mathrm{Fe}^{2+}$ concentration changes (or changes of other electron donors such as $\mathrm{HS}^{-}$) may affect the balance between DNRA and denitrification (e.g., Robertson et al., 2015). Hence, in addition to the direct regulating effects of $\mathrm{O}_{2}$ on the partitioning between denitrification and DNRA, which we have demonstrated here experimentally, $\mathrm{O}_{2}$ can act as an indirect regulator of fixed$\mathrm{N}$ elimination versus regeneration. The ultimate ecosystemscale DNRA / denitrification ratio in environments that are subject to fluctuating $\mathrm{O}_{2}$ conditions is difficult to predict because direct and indirect $\mathrm{O}_{2}$ regulation may act concomitantly and in opposite ways.

\section{Conclusions}

The presented results broaden the range of $\mathrm{O}_{2}$ inhibition thresholds of benthic denitrification at micromolar $\mathrm{O}_{2} \mathrm{lev}$ els, demonstrating that benthic denitrification may resist full inhibition up to almost $80 \mu \mathrm{M} \mathrm{O}$. Similarly, sedimentary DNRA does not necessarily require true anoxia and was even less sensitive than denitrification to higher $\mathrm{O}_{2}$ levels. Our data suggest that the balance between DNRA and denitrification is modulated by $\mathrm{O}_{2}$ at the nitrate-reducing enzyme level. However, more in-depth investigations on the exact role of oxygen in regulating other denitrification and/or nitrate-ammonification enzymes in microbial pure culture experiments are needed. The differential tolerance of denitrifiers versus nitrate ammonifiers towards $\mathrm{O}_{2}$ has important implications for natural environments with fluctuating $\mathrm{O}_{2}$ conditions. Based on our results, one might argue that DNRA may be more important during phases of bottom-water oxygenation, while anoxic conditions during the stratification period may favour full denitrification to dinitrogen. Whether and when fixed nitrogen is preserved in a lake or eliminated by denitrification is, however, difficult to predict, as this will also depend on multiple indirect effects of changing $\mathrm{O}_{2}$ levels. For example, nitrification and the redox-dependent modulation of substrates that may be relevant for denitrification or DNRA (such as nitrite, the substrate at the branching point between the two processes, and/or sulfide as potential inhibitor of denitrification and stimulator of chemolithotrophic DNRA) will play an important role with regards to both the overall nitrate reduction rate and the balance between different nitrate-reducing processes. Internal eutrophication from $\mathrm{N}$ in high-productivity lakes is generally less of a concern than from P. Nevertheless, it needs to be considered that oxygenation may reduce the overall fixed-N elimination capacity of the bottom sediments by impairing denitrification more than DNRA, partially counteracting the generally positive effects of hypolimnetic ventilation in the context of benthic nutrient retention/elimination, and with implications on the nutrient status in the water column.

Data availability. Data can be accessed upon request to the corresponding author.

Supplement. The supplement related to this article is available online at: https://doi.org/10.5194/bg-16-4705-2019-supplement.

Author contributions. JZ and MFL initiated the project. ANYC performed all sample collection and conducted the experimental work with help from AG. FL provided the water column chemistry profiles. ANYC, JZ and MFL performed data analysis and interpretation. ANYC and MFL prepared the paper with input from all co-authors.

Competing interests. The authors declare that they have no conflict of interest.

Acknowledgements. We thank Thomas Kuhn for technical support in the laboratory and Stefano Beatrizotti, Maciej Bartosiewicz, Guangyi Su and Jana Tischer for assistance during sampling on the lake. We also thank Elizabeth Robertson and Bo Thamdrup for their help during the development of the method for slurry incubation experiments.

Financial support. This research has been supported by the Swiss National Science Foundation (SNF) (project no. 153055 granted to Jakob Zopfi and Moritz F. Lehmann), and by the Freiwillige Akademische Gesellschaft (FAG) Basel.

Review statement. This paper was edited by Perran Cook and reviewed by two anonymous referees. 


\section{References}

An, S. and Gardner, W. S.: Dissimilatory nitrate reduction to ammonium (DNRA) as a nitrogen link, versus denitrification as a sink in a shallow estuary (Laguna Madre/Baffin Bay, Texas), Mar. Ecol. Prog. Ser., 237, 41-50, https://doi.org/10.3354/meps237041, 2002.

Babbin, A. R., Keil, R. G., Devol, A. H., and Ward, B. B.: Organic matter stoichiometry, flux, and oxygen control nitrogen loss in the ocean, Science, 344, 406-408, https://doi.org/10.1126/science.1248364, 2014.

Bateman, E. J. and Baggs, E. M.: Contributions of nitrification and denitrification to $\mathrm{N}_{2} \mathrm{O}$ emissions from soils at different water-filled pore space, Biol. Fertil. Soils, 41, 379-388, https://doi.org/10.1007/s00374-005-0858-3, 2005.

Baumann, B., Snozzi, M., Zehnder, A. J. B., and van der Meer, J. R.: Dynamics of denitrification activity of Paracoccus denitrificans in continuous culture during aerobic-anaerobic changes, J. Bacteriol., 178, 4367-4374, https://doi.org/10.1128/jb.178.15.43674374.1996, 1996

Baumann, B., Snozzi, M., van der Meer, J. R., and Zehnder, A. J. B.: Development of stable denitrifying cultures during repeated aerobic-anaerobic transient periods, Water Res., 31, 1947-1954, https://doi.org/10.1016/S0043-1354(97)00053-5, 1997.

Blees, J., Niemann, H., Wenk, C. B., Zopfi, J., Schubert, C. J., Jenzer, J. S., Veronesi, M., and Lehmann, M. F.: Bacterial methanotrophs drive the formation of a seasonal anoxic benthic nepheloid layer in an alpine lake, Limnol. Oceanogr., 59, 1410-1420, https://doi.org/10.4319/lo.2014.59.4.1410, 2014.

Bowles, M. W., Nigro, L. M., Teske, A. P., and Joye, S. B.: Denitrification and environmental factors influencing nitrate removal in Guaymas Basin hydrothermally altered sediments, Front. Microbiol., 3, 1-11, https://doi.org/10.3389/fmicb.2012.00377, 2012.

Braman, R. S. and Hendrix, S. A.: Nanogram nitrite and nitrate determination in environmental and biological materials by vanadium(III) reduction with chemiluminescence detection, Anal. Chem., 61, 2715-2718, https://doi.org/10.1021/ac00199a007, 1989.

Brunet, R. C. and Garcia-Gil, L. J.: Sulfide-induced dissimilatory nitrate reduction to ammonia in anaerobic freshwater sediments, FEMS Microbiol. Ecol., 21, 131-138, https://doi.org/10.1016/0168-6496(96)00051-7, 1996.

Burgin, A. J. and Hamilton, S. K.: Have we overemphasized the role of denitrification in aquatic ecosystems? A review of nitrate removal pathways, Front. Ecol. Environ., 5, 89-96, 2007.

Carter, J. P., Hsiao Y.A., Spiro, S., and Richardson, D. J.: Soil and sediment bacteria capable of aerobic nitrate respiration, Appl. Environ. Microbiol., 61, 2852-2858, 1995.

Cojean, A. N. Y., Lehmann, M. F., Robertson, E. K., Thamdrup, B., and Zopfi, J.: Controls of inorganic substrates $\left(\mathrm{H}_{2} \mathrm{~S}, \mathrm{Fe}^{2+}\right.$, $\mathrm{Mn}^{2+}$ ) on $\mathrm{NO}_{3}^{-}$-reducing processes in surface sediments of an eutrophic lake, in preparation, 2019.

Dalsgaard, T., Stewart, F. J., Thamdrup, B., De Brabandere, L., Revsbech, N. P., Ulloa, O., Canfield, D. E., and DeLong, E. F.: Oxygen at nanomolar levels reversibly suppresses process rates and gene expression in anammox and denitrification in the oxygen miminum zone off northern Chile, mBio, 5, e01966, https://doi.org/10.1128/mBio.01966-14, 2014.

Dong, L. F., Sobey, M. N., Smith, C. J., Rusmana, I., Phillips, W., Stott, A., Osborn, A. M., and Nedwell, D. B.: Dissimilatory re- duction of nitrate to ammonium, not denitrification or anammox, dominates benthic nitrate reduction in tropical estuaries, Limnol. Oceanogr., 56, 279-291, 2011.

Fazzolari, É., Nicolardot, B., and Germon, J. C.: Simultaneous effects of increasing levels of glucose and oxygen partial pressures on denitrification and dissimilatory nitrate reduction to ammonium in repacked soil cores, Eur. J. Soil Biol., 34, 47-52, https://doi.org/10.1016/S1164-5563(99)80006-5, 1998.

Froelich, P. N., Klinkhammer, G. P., Bender, M. L., Luedke, N. A., Heath, G. R., Gullen, D., Dauphin, P., Hammond, D., and Hartman, B.: Early oxidation of organic matter in pelagic sediments of the eastern equatorial Atlantic: suboxic diagenesis, Geochim. Cosmochim. Ac., 43, 1075-1090, 1979.

Gao, H., Schreiber, F., Collins, G., Jensen, M. M., Kostka, J. E., Lavik, G., De Beer, D., Zhou, H. Y., and Kuypers, M. M. M.: Aerobic denitrification in permeable Wadden Sea sediments, ISME J., 4, 417-426, https://doi.org/10.1038/ismej.2009.127, 2010.

Garcia, H. E. and Gordon, L. I.: Oxygen solubility in seawater: Better fitting equations, Limnol. Oceanogr., 37, 1307-1312, 1992.

Glud, R. N.: Oxygen dynamics of marine sediments, Mar. Biol. Res., 4, 243-289, https://doi.org/10.1080/17451000801888726, 2008.

Gruber, N. and Galloway, J. N.: An Earth-system perspective of the global nitrogen cycle, Nature, 451, 293-296, https://doi.org/10.1038/nature06592, 2008.

Hansen, H. P. and Koroleff, F.: Determination of nutrients, in Methods of Seawater Analysis, 3rd Edn., Verlag Chemie, Weinheim, Wiley-VCH, 159-228, 1999.

Hietanen, S. and Lukkari, K.: Effects of short-term anoxia on benthic denitrification, nutrient fluxes and phosphorus forms in coastal Baltic sediment, Aquat. Microb. Ecol., 49, 293-302, https://doi.org/10.3354/ame01146, 2007.

Jäntti, H. and Hietanen, S.: The effects of hypoxia on sediment nitrogen cycling in the Baltic Sea, Ambio, 41, 161-169, https://doi.org/10.1007/s13280-011-0233-6, 2012.

Jensen, M. M., Kuypers, M. M. M., Lavik, G., and Thamdrup, B.: Rates and regulation of anaerobic ammonium oxidation and denitrification in the Black Sea, Limnol. Oceanogr., 53, 23-36, https://doi.org/10.4319/lo.2008.53.1.0023, 2008.

Jensen, M. M., Petersen, J., Dalsgaard, T., and Thamdrup, B.: Pathways, rates, and regulation of $\mathrm{N}_{2}$ production in the chemocline of an anoxic basin, Mariager Fjord, Denmark, Mar. Chem., 113, 102-113, https://doi.org/10.1016/j.marchem.2009.01.002, 2009.

Kalvelage, T., Jensen, M. M., Contreras, S., Revsbech, N. P., Lam, P., Günter, M., LaRoche, J., Lavik, G., and Kuypers, M. M. M.: Oxygen sensitivity of anammox and coupled Ncycle processes in oxygen minimum zones, PLoS One, 6, 1-12, https://doi.org/10.1371/journal.pone.0029299, 2011.

Kamp, A., de Beer, D., Nitsch, J. L., Lavik, G., and Stief, P.: Diatoms respire nitrate to survive dark and anoxic conditions, P. Natl. Acad. Sci. USA, 108, 5649-54, https://doi.org/10.1073/pnas.1015744108, 2011.

Kaspar, H. F.: Denitrification, nitrate reduction to ammonium, and inorganic nitrogen pools in intertidal sediments, Mar. Biol., 74, 133-139, 1983.

Körner H. and Zumft, W. G.: Response to the dissolved oxygen level and respiratory substrate in continuous culture of Pseudomonas stutzeri, 55, 1670-1676, 1989. 
Kraft B., Tegetmeyer, H. E., Sharma, R., Klotz, M. G., Ferdelman, T. G., Hettich, R. L., Geelhoed, J. S., and Strous, M.: The environmental controls that govern the end product of bacterial nitrate respiration, Sciences, 345, 676-679, 2014.

Lazzaretti, M. A. and Hanselmann K. W., Brandl, H., Span, D., and Bachofen, R.: The role of sediments in the phosphorous cycle in Lake Lugano, Seasonal and spatial variability of microbiological processes at the sediment-water surface, Aquat. Sci., 54, 285299, https://doi.org/10.1007/BF00878141, 1992.

Lehmann, M. F., Bernasconi, S. M., McKenzie, J. A., Barbieri, A., Simona, M., and Veronesi, M.: Seasonal variation of the $\delta^{13} \mathrm{C}$ and $\delta^{15} \mathrm{~N}$ of particulate and dissolved carbon and nitrogen in Lake Lugano: Constraints on biogeochemical cycling of eutrophic lake, Limnol. Oceanogr., 49, 415-429, 2004.

Lehmann, M. F., Barnett, B., Gélinas, Y., Gilbert, D., Maranger, R. J., Mucci, A., Sundby, B., and Thibodean, B.: Aerobic respiration and hypoxia in the Lower St. Lawrence Estuary?: Stable isotope ratios of dissolved oxygen constrain oxygen sink partitioning, Limnol. Oceanogr., 54, 2157-2169, https://doi.org/10.4319/lo.2009.54.6.2157, 2009.

Lehmann, M. F., Simona, M., Wyss, S., Blees, J., Frame, C. H., Niemann, H., Veronesi, M., and Zopfi, J.: Powering up the "biogeochemical engine": the impact of exceptional ventilation of a deep meromictic lake on the lacustrine redox, nutrient, and methane balances, Front. Earth Sci., 3, 1-13, https://doi.org/10.3389/feart.2015.00045, 2015.

Mohan, S. B. and Cole, J. A.: The dissimilatory reduction of nitrate to ammonia by anaerobic bacteria, in: Biology of the Nitrogen Cycle, edited by: Bothe H., Ferguson S., and Newton W. E., Elsevier B.V., 93-106, 2007.

Moir, J. W. B. and Wood, N. J.: Nitrate and nitrite transport in bacteria, Cell. Mol. Life Sci., 58, 215-224, 2001.

Morley, N. and Baggs, E. M.: Carbon and oxygen controls on $\mathrm{N}_{2} \mathrm{O}$ and $\mathrm{N}_{2}$ production during nitrate reduction, Soil Biol. Biochem., 42, 1864-1871, https://doi.org/10.1016/j.soilbio.2010.07.008, 2010.

Morley, N., Baggs, E. M., Peter, D., and Bakken, L.: Production of $\mathrm{NO}, \mathrm{N}_{2} \mathrm{O}$ and $\mathrm{N}_{2}$ by extracted soil bacteria, regulation by $\mathrm{NO}_{2}^{-}$ and $\mathrm{O}_{2}$ concentrations, FEMS Microbiol. Ecol., 65, 102-112, https://doi.org/10.1111/j.1574-6941.2008.00495.x, 2008.

Nielsen, L. P.: Denitrification in sediment determined from nitrogen isotope pairing, FEMS Microbiol. Ecol., 86, 357-362, https://doi.org/10.1016/0378-1097(92)90800-4, 1992.

Otte, S., Grobben, N. G., Robertson, L. A., Jetten, M. S. M., and Kuenen, J. G.: Nitrous oxide production by Alcaligenes faecalis under transient and dynamic aerobic and anaerobic conditions, Appl. Environ. Microbiol., 62, 2421-2426, 1996.

Papaspyrou, S., Smith, C. J., Dong, L. F., Whitby, C., Dumbrell, A. J., and Nedwell, D. B.: Nitrate reduction functional genes and nitrate reduction potentials persist in deeper estuarine sediments. Why ?, PLoS One, 9, e94111, https://doi.org/10.1371/journal.pone.0094111, 2014.

Patureau, D., Zumstein, E., Delgenes, J. P., and Moletta, R.: Aerobic denitrifiers isolated from diverse natural and managed ecosystems, Microb. Ecol., 39, 145-152, https://doi.org/10.1007/s002480000009, 2000.

Paulmier, A. and Ruiz-Pino, D.: Oxygen minimum zones (OMZs) in the modern ocean, Prog. Oceanogr., 80, 113-128, https://doi.org/10.1016/j.pocean.2008.08.001, 2009.
Payne, E. K., Burgin, A. J., and Hamilton, S. K.: Sediment nitrate manipulation using porewater equilibrators reveals potential for $\mathrm{N}$ and S coupling in freshwaters, Aquat. Microb. Ecol., 54, 233 241, https://doi.org/10.3354/ame01272, 2009.

Poock, S. R., Leach, E. R., Moir, J. W. B., Cole, J. A., and Richardson, D. J.: Respiratory detoxification of nitric oxide by the cytochrome c nitrite reductase of Escherichia coli, J. Biol. Chem., 277, 23664-23669, https://doi.org/10.1074/jbc.M200731200, 2002.

Prokopenko, M. G., Hirst, M. B., De Brabandere, L., Lawrence, D. J., Berelson, W. M., Granger, J., Chang, B. X., Dawson, S., Crane 3rd, E. J., Chong, L., Thamdrup, B., Townsend-Small, A., and Sigman, D. M.: Nitrogen losses in anoxic marine sediments driven by Thioploca-anammox bacterial consortia, Nature, 500, 194-198, https://doi.org/10.1038/nature12365, 2013.

Rao, A. M. F., McCarthy, M. J., Gardner, W. S., and Jahnke, R. A.: Respiration and denitrification in permeable continental shelf deposits on the South Atlantic Bight: Rates of carbon and nitrogen cycling from sediment column experiments, Cont. Shelf Res., 27, 1801-1819, https://doi.org/10.1016/j.csr.2007.03.001, 2007.

Richardson, D. J., van Spanning R. J. M., and Ferguson S. J.: The prokaryotic nitrate reductases, in: Biology of the nitrogen cycle, edited by: Bothe, H., Ferguson, S. J., and Newton, W. E., Elsevier B.V., 21-35, 2007.

Risgaard-Petersen, N., Rysgaard, S., and Revsbech, N. P.: Combined microdiffusion-hypobromite oxidation method for determining nitrogen-15 isotope in ammonium, Soil Sci. Soc. Am., 59, 1077-1080, 1995.

Roberts, K. L., Eate, V. M., Eyre, B. D., Holland, D. P., and Cook, P. L. M.: Hypoxic events stimulate nitrogen recycling in a shallow salt-wedge estuary: The Yarra River estuary, Australia, Limnol. Oceanogr., 57, 1427-1442, https://doi.org/10.4319/lo.2012.57.5.1427, 2012.

Roberts, K. L., Kessler, A. J., Grace, M. R., and Cook, P. L. M.: Increased rates of dissimilatory nitrate reduction to ammonium (DNRA) under oxic conditions in a periodically hypoxic estuary, Geochim. Cosmochim. Ac., 133, 313-324, https://doi.org/10.1016/j.gca.2014.02.042, 2014.

Robertson, E. K., Roberts, K. L., Burdorf, L. D. W., Cook, P., and Thamdrup, B.: Dissimilatory nitrate reduction to ammonium coupled to $\mathrm{Fe}(\mathrm{II})$ oxidation in sediments of a periodically hypoxic estuary, Limnol. Oceanogr., 61, 365-381, https://doi.org/10.1002/lno.10220, 2016.

Robertson, L. A., Dalsgaard, T., Revsbech, N., and Kuenen, J. G.: Confirmation of 'aerobic denitrification' in batch cultures, using gas chromatography and ${ }^{15} \mathrm{~N}$ mass spectrometry, FEMS Micriobiology Ecol., 18, 113-120, 1995.

Rysgaard, S., Risgaard-petersen, N., and Sloth, N. P.: Nitrification, denitrification, and nitrate ammonification in sediments of two coastal lagoons in Southern France, Hydrobiologia, 329, 133141, 1996.

Seitzinger, S. P.: Denitrification in freshwater and coastal marine ecosystems: Ecological and geochemical significance, Limnol. Oceanogr., 33, 702-724, 1988.

Seitzinger, S., Harrison, J. A., Böhlke, J. K., Bouwman, A. F., Lowrance, R., Peterson, B., Tobias, C., and van Drecht, G.: Denitrification across landscapes and waterscapes: A synthesis, Ecol. Appl., 16, 2064-2090, 2006. 
Simon, J. and Klotz, M. G.: Diversity and evolution of bioenergetic systems involved in microbial nitrogen compound transformations, Biochim. Biophys. Ac., 1827, 114-135, 2013.

Thamdrup, B. and Dalsgaard, T.: Production of $\mathrm{N}_{2}$ through anaerobic ammonium oxidation coupled to nitrate reduction in marine sediments, Appl. Environ. Microbiol., 68, 1312-1318, 2002.

Smith, E. J., Davison, W., and Hamilton-Taylor, J.: Methods for preparing synthetic freshwaters, Water Res., 36, 1286-1296, 2002.

Thauer, R. K., Jungermann, K., and Decker, K.: Energy conservation in chemotrophic anaerobic bacteria, Bacteriol. Rev., 41, 100-180, https://doi.org/10.1073/pnas.0803850105, 1977.

Tiedje, J. M.: Ecology of denitrification and dissimilatory nitrate reduction to ammonium, in: Environmental microbiology of anaerobes, edited by: Zehnder, A. J. B., John Wiley and Sons, NewYork, 179-244, 1988.
Wenk, C. B., Zopfi, J., Gardner, W. S., McCarthy, M. J., Niemann, H., Veronesi, M., and Lehmann, M. F.: Partitioning between benthic and pelagic nitrate reduction in the Lake Lugano south basin, Limnol. Oceanogr., 59, 1421-1433, https://doi.org/10.4319/lo.2014.59.4.1421, 2014.

Zehr, J. P. and Ward, B. B.: Nitrogen Cycling in the Ocean?: New perspectives on processes and paradigms, Appl. Environ. Microbiol., 68, 1015-1024, 2002.

Zopfi, J., Kjær, T., Nielsen, L. P., and Jørgensen, B. B.: Ecology of Thioploca spp.: Nitrate and sulfur storage in relation to chemical microgradients and influence of Thioploca spp. on the sedimentary nitrogen cycle, Appl. Environ. Microbiol., 67, 5530-5537, https://doi.org/10.1128/AEM.67.12.5530-5537.2001, 2001. 